\title{
La Peña de los Parra: The Power of Song Carolyne Wright
}

ON WEEKEND EVENINGS in late 1971 and early 1972-the uneasy middle months of Salvador Allende's presidency, when I was a 22-year-old student in Chile on a Fulbright Study Grant - my friends and I boarded one of Santiago's big rattletrap busses down the Alameda to a neighborhood of run-down mansions and working-class flats. We got off at the Calle Carmen and walked down to No. 340, where we paid the 20-escudo cover charge and sat at one of the rickety low tables in the dark, already crowded room, to wait for the spotlight to come on and the first performers to step onto the tiny stage. The place was the Peña de los Parra, the folk music club and gallery/atelier of popular art, opened in 1965 by Isabel and Angel Parra, daughter and son of the legendary Violeta Parra, the folk musician and artist who had died in early 1967.

My friends and I knew that the Peña was the center of La Nueva Canción - the Chilean New Song movement - and part of the renaissance of folk literature, art, theatre and dance that flowered so briefly in Chile in the 1960s and early 70s. But none of us could have foreseen how abruptly this movement would be cut off in September, 1973, by the military coup. All we knew then was that we admired the music-its energy and authenticity - and the artistic and social commitment of its practitioners: groups like Quilapayún and Inti-Illimani, solo performers like Osvaldo Rodríguez and the already world-renowned Victor Jara (who was to be tortured and murdered after the coup by the military police in Santiago's National Stadium), as well as Angel and Isabel themselves. Their names would become synonymous throughout Latin America, and later, throughout the world, with the power of song as a weapon.

I first heard of the Peña from a former Fulbright fellow, Alan Jacobs, who had stayed on in Chile and was now teaching history at Nido de Aguilas, the American school for diplomats' children. We met at one of the few Embassy parties I attended early in my stay; he asked me if I had heard any Chilean folk music yet. I hadn't, so the next week he invited me to his house, a big shabby Tudor-style mansion on Vitacura Avenue. Most of its 
rooms were rented to foreigners: Argentine or Peruvian students, and a group of Brazilians whom I could hear laughing and talking all at once in the kitchen as we walked past. Alan had an old record player and a collection of Chilean LP's. I looked at the names on the jackets: Hilda Parra, Violeta Parra, Isabel and Angel Parra, among others.

"Why are so many of these singers named Parra?" I asked.

"They're all related," Alan said. "They have a club downtown, on Carmen Street. A great place to hear the real music, not the touristy stuff you get at the hotels. This is the one you have to listen to." He handed me an album: "Las Ultimas Composiciones de Violeta Parra." The black and white photo that took up the front of the record jacket showed a small woman in a nondescript wool dress, sitting and strumming a charango, a tiny instrument resembling a ukelele, made from the body of an armadillo. The woman's mouth was open as she sang, revealing small uneven teeth. She might have been a campesina from the provinces. I couldn't tell her age. Her hair was like a young woman's - loose, tangled, falling to her waist - except for its color, an overall iron gray. Her face was somehow ageless - the skin smooth, features subtly Indian - a face not pretty, but alive with a contained intensity or passion, less sensual than emotive, yearning.

"I want to go hear her at that club," I said.

"You can't," said Alan. "She's dead. Suicide - over a man, I think."

On the back of the album, under the list of song titles, was a small photo, crudely cut out around its edges, of a young man in profile: short beard, gaunt face with high mestizo cheekbones, head bent forward as if listening to the beat of the drum he was holding. He was Alberto Zapicán, who accompanied Violeta on the record, playing the bombo-the pinto horsehide-covered drum - and singing in a voice that broke as it climbed to the high notes of the laments. It was music full of the sun-cracked Atacama Desert, the jagged Andean ranges, the windy isolation of the altiplano, the high rocky plateau of Bolivia and the north of Chile. "Arriba quemando el sol," sang Violeta and Alberto: the sun burning overhead, the sky like a hell without a door.

Alberto Zapicán was the man Violeta had loved. His photo on the back of the album was a quiet statement for those aware of the circumstances, who already knew its meaning. People I asked didn't seem to want to talk about what had happened. I heard a version of the story later, from a friend who spent a lot of time at the Peña. According to this story, Violeta had 
never married, but she had had three children who bore her name: Angel and Isabel, who had inherited their mother's musical gifts and who directed and performed at the Peña; and Carmen, the younger daughter, who had been too young to go to Paris with the others in the early 60s, and whom I heard sing once at the Peña in a flat, quavering voice, so that people felt sorry for her because she wasn't gifted like the other two.

At the time Violeta started collaborating with Alberto, she was almost fifty. She had spent her life travelling the length and breadth of Chile, collecting and transcribing traditional songs, and living with the farmers, herders, miners, fishermen, weavers, and folk healers whose songs they were. She had been a cuequera, playing the traditional dance's music at weddings, festivals, and bars in small towns and villages; she had sung at all-night wakes for children: songs "to the divine" spirit of the deceased, and "to the human" of the survivors, mourners whose sorrow turned to jubilation and triumph over death by dawn. She had composed and performed her own songs, and recorded her first album in Paris in 1964. The arpilleras, tapestries she stitched from hand-dyed homespun wool in her own designs, were exhibited in the Louvre the same year, while she and her two older children lived in Paris, playing in clubs in the Latin Quarter, and touring through Europe and the Soviet Union. She returned to Chile with Isabel and Angel in 1965, and they opened the Peña de los Parra soon thereafter. Her brother, the poet Nicanor Parra, wrote an "Homage to Violeta Parra" for her:

When it comes to dancing the cueca

No one gets free from your guitar.

Even the dead come out to dance

A waltzing cueca.

But the bureaucrats can't stand you,

They board up the door of your house

Declaring war to the death against you,

Sorrowful Violeta.

Because you don't buy or sell yourself

Because you don't dress up like a clown

Because you speak the language of the earth,

Viola chilensis. 
Even Pablo Neruda, playing on the meaning of Parra (honeycomb), had written of her, "Honeycomb you are / and into sad wine you turn yourself."

I listened to Alan's copy of her last compositions, and later bought my own. The songs on it remained close to me throughout my time in Chile, and for years afterwards. Violeta's voice was unpolished-nasal, flat at times on the low notes, strident on the high-but always lyrical, a voice that seemed to come right out of the earth of Chile. Everything she sang grew urgent with the urgency of her voice. In "Maldigo el alto cielo" (I Curse the High Heavens), Violeta, accompanied by Alberto, listed all the states, conditions, and injustices of mankind that they abhorred. "Run Run se fue pa'l norte" was a lament for the journey the singer's lover took to the North, to the Atacama Desert, to be alone, to struggle toward some understanding of his relationship with her, to figure out how to break it off:

\author{
Run Run's gone up to the North \\ Who knows when he'll return, \\ Return for the birthday \\ Party of our solitude.
}

Alberto Zapicán was twenty years younger than Violeta. They had begun by playing together at the Peña, and she had fallen in love with him. One night after a rehearsal, according to my friend's story, Violeta had finally told Alberto of her feelings, had offered herself to him. He regarded her as a great artist and mentor; he could not reciprocate, would not become her lover. Soon after that, in February of 1967, alone in her house in La Reina, a village on the outskirts of Santiago, Violeta Parra committed suicide.

Her final album was released after her death. Its first song, "Gracias a la vida," so clearly premonitory in its loving farewell to the life which had given her so much sorrow and joy, was Violeta's greatest composition. In each verse, she thanked one of the five senses which had allowed her to know the sounds, colors, tastes, and smells of the earth, and the love for one man:

Thanks to life, which has given me so much,

Given me two eyes, that when I open them 
I can tell perfectly black from white, In the high heavens, their starry depths, And in the crowds, the man I love.

Thanks to life, which has given me so much, Given me a heart that quickens its pace When I see the fruit of the human brain, When I see good so distant from evil, When I look into the depths of your clear eyes.

Thanks to life, which has given me so much, Given me laughter and given me tears, Thus I distinguish joy from grief, The two materials that form my song And the song of all of you That is the same song And the song of everyone That is my own song ...

The voice faded out in a final haunting cry: "Gracias a la vida, que me ha dado tanto. ..." It was human love for the earth and for fellow human beings that was the highest truth of Violeta's life: the love of the campesino for the land which sustained him, the love of the fisherman of Chiloe for the sea, the Mapuche Indian woodcutter for the once-vast forests of Arauco and Toltén, the love of the mother for her child, of man for woman, andalways - of woman for man. And it was human love she felt had betrayed her when she took her life.

There was another woman whose presence in the Peña became evident to me from my first visits. She sat by herself on a bench next to the stage, dressed like a student in faded blue jeans and a brown Bolivian poncho with llamas parading around its border, her glass of wine forgotten on the table beside her. She seemed to be alone; at least I never saw her speak to anyone near her. Often she held a charango, one hand supporting the instrument's tiny body, the other making the performers' chord changes. She looked to be about twenty.

I couldn't tell her nationality. Her features were Oriental; she could 
have been Bolivian, or from the Far East. But in racially exclusionist Chile, the middle and upper classes were almost purely European: descendants of Hispanic, English, Slavic, and (after World War II) German immigrants. The lower one looked on the socio-economic ladder, the more one saw the black hair, stocky body structure, and East Asian features of the mestizo or pure Indian. It was a sad comment on the persistence of colonial attitudes that in a country where the majority of the people were of mixed descent, with Mapuche and other tribal strains predominating, words like cholo and indio were among the strongest insults one could utter. Except for a few diplomats or other foreign government employees, there were virtually no Asians and no blacks. And even though the Peña promoted the authentic music of the campo and the pueblo - the rural poor and urban masses -its audiences were almost entirely middle-class: university students, European tourists, and those intellectuals and professional people who supported Allende. (During the day, of course, the Peña did sponsor classes in artisanry and crafts such as weaving and embroidery for poor women from the poblaciones, the shantytowns of Santiago; but by 10 P.M., when the musical program began, these women and their families would be asleep in their shacks, to rise at dawn for their long days of ill-paid labor.) So this young woman's presence in the Peña was unusual, and aroused my curiosity.

Soon after that, I began to attend classes at the Universidad Católica's Faculty of Fine Arts. It was close to where I lived, and less subject to the strikes and closures that made getting an education at the highly politicized public Universidad de Chile a perpetual challenge for students. The Catholic University was attended mainly by the children of Santiago's more wellto-do families, but it did provide some scholarship aid to poorer applicants. On one of my first visits there, I noticed the young Oriental woman I had seen at the Peña, standing in a studio doorway and talking to a few other students. I asked some of my printmaking classmates who she was.

"Oh, that's Harumi," one of them said. "She's pretty strange." This was Rogerio Ruíz Amunátegui, a rich kid with an Elvis Presley ducktail who had his own Fiat and once took a group of us after an evening class to one of the only fast-food drive-ins in the city, a fried chicken hangout called the "Pollo Stop." This was early on in my time at the Art School, before Rogerio and his friends realized that I was not cut out to be one of their set. I was never asked along again. 
"But the gringa might like Harumi, they might have something in common," said another fellow, a tall gangly boy named Vicente with a thin face, protruding teeth, and a perpetually sheepish expression. The other students called him Inocente, and behind his back, Simple.

"Like what?" Rogerio was annoyed. "You think the gringa would like those Commies Harumi hangs around with?" I'd acquired the nickname gringa right away, and others at the Art School fell quickly into the habit of referring to me in my presence in the third person. Some never did know my real name.

I tried a few times to talk to Harumi in the school cafeteria, a big chilly room with a concrete floor and unfinished plywood walls in a style that passed for contemporary in Santiago. The students sat eating at long rickety tables, observing the informal but clear-cut social divisions of much longer standing than the architecture. Tables in one area were occupied by barrio alto students: slender blond or brunette young men and women in well-cut outfits, who spread their portfolios over several chairs and lounged comfortably for hours, talking loudly and laughing with that moneyed ease I remembered so well from the country club crowd that ignored me in high school. At other tables scattered along the walls and at the far end of the room sat the students from the working-class neighborhoods in the industrial sectors below the city center, and the few special scholarship students from the poblaciones. They hunched over bread and chilis brought from home, talking in low voices and finishing rapidly to get back to the studios or to part-time jobs for the school. Almost all were brown-skinned and black-haired, mestizo. Men and women alike wore the denim trousers which passed for blue jeans in Chile, and denim jackets or the big shapeless sweaters which peasant women knitted for their families. In my recollection, these students are always sitting close together with their backs to me and to the barrio alto rich kids (with whom, in their minds, I must have been grouped). They keep to themselves, and seem to be trying to remain as inconspicuous as possible.

I wondered what careers they would pursue after the Art School. The rich boys would go into their fathers' businesses, or take jobs with advertising and design firms in Santiago. The rich girls would marry the rich boys; and, when not relaxing at the golf clubs or shopping at fashionable boutiques along Providencia Avenue, they might design jewelry or party frocks, or open their own boutiques, where their former school friends 
could gather for tea and games of canasta, and where they might sell a few items to tourists, the only people not of their own set who wandered into such shops. The poor girls might be lucky enough to get teaching jobs in the provinces or at schools in the same Santiago neighborhoods where they grew up. The poor boys might do paste-up or paint signboards for the same companies into which the rich boys would step as junior managers, or they might be hired to do layout for El Clarín or La Vanguardia or one of the other left-wing newspapers sympathetic to the working class. One thing about their futures was certain: the two classes would have little interaction, and no more to say to each other in the working world than they did now.

Harumi seemed to hover somewhere between the two groups of tables in the cafeteria, but whenever I walked in, she was just picking up her satchel and hurrying out. She nodded at me as she passed; she seemed to know who I was. Often she looked withdrawn and tired. "It's those drugs she takes," Rogerio said.

Once when I was in the printmaking studio, behind the partition where the rolling blocks and trays of nitric acid were laid out on a long table, trying to get the resin to set properly on a copper plate, I overheard Rogerio and some of his friends talking about Harumi. Apparently she had missed a critiquing session in the painting class that morning, and Professor Salazar had asked if anyone knew where she was.

"So I told him she was out all night with her drug-addict Commie friends," Rogerio laughed. "Everybody thought it was funny, but Salazar was pissed."

"Salazar's one of them, too," another fellow said. "He goes out with Matta and the Ramona Parra gang."

Roberto Matta was Chile's best-known painter; he had had shows in Buenos Aires and Paris and Rome, and was beginning to acquire some reputation in the United States. It was common knowledge that he also supervised and led a group of young graffitti artists, the Ramona Parra Brigade, on late-night painting forays around Santiago. The Brigade specialized in pro-Allende political slogans, adorned with boldly outlined illustrations of demonstrators, Chilean flags, portraits of Ché Guevara and Fidel Castro, drawings of laborers in factories and campesina mothers in the fields with their babies strapped to their backs. These artists used only black and bright primary colors, and they worked at lightning speed in darkness to 
avoid getting caught by the police. Walls and ground-floor facades of buildings were covered with their creations; no wall in the city remained freshly whitewashed for long without being marked by their efforts, or those of their imitators or right-wing Patria $y$ Libertad (Fatherland and Freedom) party opponents. Before Allende was elected, the Ramona Parra and other graffitti brigades were strictly illegal. If apprehended, members of the group faced stiff jail sentences. But Matta's growing international reputation in the art world had already begun to confer on the various brigades a certain immunity, even before Allende's September, 1970, electoral victory.

"Yeah, Ramona Parra," Rogerio said. Then he repeated it, changing the last name to Porra, one of the more obscene sexual terms in Spanish.

"Violeta Porra, too," said his friend, and they all laughed. "That's what Harumi needs." Still laughing, they left the studio. I was glad they hadn't noticed me behind the partition.

After the printmaking workshop that afternoon, I told Vicente what I had overheard.

"You know what Harumi really does?" he asked. I said I didn't.

"Volunteer work at one of the mothers' centers, I don't know where, Renca or Barrancas or one of those poblaciones. And don't tell anyone," he lowered his voice, glancing across the studio where a few other students were putting supplies away in the cabinets. "I went with her last year to a Ramona Parra meeting. Right after Allende was elected. We did a whole wall along the river with victory slogans." Vicente grinned. "I was wiped out for two days after that."

I finally went to see Harumi in the painting studio where she often worked late into the night. She greeted me with a casual "Hola, gringa," as if she had known all along I'd be coming.

I told her I'd like to see some of her work. She set down her brush and palette and pulled out some charcoal figure studies and a few abstract oils with swirling vortices of color in muted tones that reminded me a little of Mark Tobey and Kenneth Callahan, Northwest painters whose oeuvre she was unlikely to be familiar with. "Your stuff's pretty good," I said.

"Thanks. But this isn't what I want to do with my life. This country needs art that reaches the people, that can make them politically conscious (she used the Popular Unity term concientizarles) so they can build a better 
society." Without referring directly to mothers' centers or the Ramona Parra Brigade, she talked about groups which were trying to carry out the ideals of the Allende platform.

"But how much can one person do here?" She made a gesture to indicate the Art School. "You can waste years in a place like this, painting baskets of fruit."

I asked her about music. She nodded and dug into her satchel, taking out a quena, the cane flute played like a recorder that I'd heard at the Peña. "There are some poor kids I sometimes play this for," she said, and launched into a musical but somewhat labored rendition of an Andean melody. "I'm not very good yet, but the kids like it, and I've got a friend teaching me."

As she cleaned and put away her brushes, she told me a little about herself. She had been born in Hiroshima, seven years after the Bomb. "But wasn't it still unsafe there?" I wondered.

She shrugged. "Even if it was, where else could people go? Japan's a small, crowded place. They had to rebuild the city."

When she was three, her father took the family first to São Paulo, with its large immigrant Japanese community, then to Santiago. She had an older brother who had returned to Japan to finish high school, and who was now at a university in Tokyo. "He says he's studying finance," she said, "but I know he's really into jazz." Her younger sister had been born in São Paulo, shortly before they came to Chile. "She's the only one of us who's completely at home here," Harumi said.

Her father, Toshiharu Kobayashi, was descended from a minor branch of a samurai family. World War II military service, the deaths of his parents and sisters in Hiroshima, and the need to work after his marriage during the American Occupation destroyed his chances for higher education; so when he left Japan, he elected to make his living in one of his family's traditional disciplines. After his son went back to Tokyo, Kobayashi continued to teach his daughters karate. Harumi said she never practiced anymore, but her sister Toshimi was pretty good, and since her father was the only teacher in Santiago, he had plenty of students.

Harumi was the freest young woman I met in Chile; at least she had the greatest freedom of movement. In that, we had one significant thing in common: even though she had lived in this country since she was nine or ten, and spoke perfect Chilean Spanish with only a slight trace of an accent, she was by virtue of her origins and race still an outsider, beyond the pale of 
social expectations - and restrictions - that applied to young Chilean women. As a gringa in both race and culture (in this city full of fair-haired, blue-eyed, middle-class native Spanish speakers who were fully Chilean), I was the only other woman I knew of in roughly the same category as Harumi. We found ourselves doing things together that would have been difficult for a woman to do alone in Chile, or to do with other Chilean women.

After our first talk at the Art School, all my subsequent visits to the Peña were with Harumi. I used to meet her at the painting studio after evening classes. She would be squatting on the floor stretching canvas, or sitting on the steps outside drinking coffee from a thermos with the male students, dressed like them in paint-spattered blue jeans and denim jacket, hunching forward into the conversation, elbows propped on her knees. The other women students had gone home an hour ago, in chattering groups headed for the bus stops on Providencia, or in their boyfriends' cars. Only Harumi stayed out as late as she liked, with whomever she chose to stay out.

We always walked out of the Art School, down the quiet street to the bridge across the Mapocho River (its retaining walls covered with bright Ramona Parra slogans and portraits) to Providencia, with its chic hairstyling salons and clothing boutiques closed for the night. The street was well-lit but deserted, except for groups of young men in sporty clothes strolling into bars and restaurant lounges; or an occasional housemaid (heavy-set, Indian features, blue bata housecoat and broken-down shoes) carrying string-bag bundles and waiting for a late bus downtown. We climbed on the same bus - one of the huge, dilapidated blue and white models (called, oddly enough, micros) that, on a Thursday evening, were practically empty. If there were no men or teenaged boys aboard, we sat at the back, Harumi taking out her quena to practice a few melodies, stopping every time the bus lurched or hit a pothole, so she wouldn't chip her teeth on the mouthpiece.

The wide street grew darker, the buildings older and grayer as we approached the center of town. At the Plaza Italia, a big traffic roundabout with a dry fountain and an equestrian statue of General Baquedano in the middle, Providencia became the Avenida Bernardo O'Higgins, "la Alameda," as everyone called it. Farther down, past the wooded Santa Lucía hill on the right, and the darkened Baroque facade of the University of Chile 
on the left, the side streets were lively, crowded with men going in and out of the working-class boliches, bars and cafes blaring pop ballads, tangos and cumbias. There, where Carmen Street intersected with the Alameda, we got off the micro.

Walking down the street was an ordeal. Two young women-one Oriental ("Boliviana," I heard some men hiss at her), one an obvious gringawere fair game at 10 P.M. on a downtown Santiago street. Men in working clothes stopped to make eyes at us, whistling or sucking air back through their teeth. The bolder ones muttered what they would do if they had us alone. From the open doors of the bars came the sour smells of alcohol and cigarettes, bursts of laughter, slurred male voices. There were no other women in sight.

Harumi shoved her hands in her pockets, hunched her shoulders under her poncho, and strode past the groups of men. If one came too close, she glanced briefly at him and said, in dialect, "Lay off, asshole." Hearing her Chilean accent, the man would step back to his gang of pals, laughing with nervous bravado, too loudly. I stayed close behind Harumi, thinking These are the people Allende is trying to help.

The wives of these men were at home, sitting in the doorways of tiny wooden shacks in the poblaciones, or on the stoops of run-down old houses converted into tenements. By now they would have cleaned up from the evening meal, put the small children to bed on blankets or straw pallets in one corner of the room, turned down the single lamp to save kerosene. They would be chatting desultorily with each other, or dozing in a chair while they could. Who knows what time their men would stagger home from the bars - surly, spoiling for an argument that would end in curses, blows, children crying, unable to fall back to sleep? It was these women and their children with whom Harumi worked at the mothers' centers set up so recently by the Allende government.

We kept walking, until the boliches gave way to dark quiet houses. Harumi always looked troubled after these exchanges with the men. "Estoy cabriada, gringa," she would say. "I'm fed up sometimes. There's so much to be done. How much can I do? Sometimes I just want to get out of here."

"Where would you go?" I asked. "Back to Japan?"

"Nah," she would shrug. "Everybody's too formal there. You have to do everything their way. And I speak really rude Japanese, none of the honorifics, that hierarchy business. There's enough of it here." She gave a 
short laugh. "My parents don't like the way I speak, but I tell them, Hey, we're not in Japan. So why act like we are?"

I was at Harumi's once, an apartment in a large brick building set back among trees on the Avenida Andrés Bello, the drive fronting the Costanera Park along the river. Her father had had an alarm system installed, Harumi said. After Allende was elected, they received several threatening phone calls - all anonymous - accusing them of being Communists and making racial insults. Her mother answered the door, a small woman with glasses and black hair in a permanent wave, bowing slightly to me and speaking in hesitant Spanish. Harumi and I went into the living room, but her mother called her back into the hall.

I looked at the black lacquered screen with a chrysanthemum motif against one wall, the scroll paintings of mist-shrouded mountains, the shelf of Japanese books. Harumi's mother was speaking to her in Japanese. Harumi's replies were low and brief. Her mother's voice rose a little. Harumi's response was very short, almost inaudible.

She rejoined me abruptly, her face expressionless. We went down the hall to her room, stopping for a moment to say hello to her sister Toshimi, a girl of nine or ten, plump, with a cropped black pageboy haircut, pink cheeks. Toshimi smiled, spoke to me in clear, slightly accented Spanish, and when we left her, resumed twirling slowly in the middle of her room, singing quietly to herself. From this brief visit (her father wasn't home at the time, and I never did meet him), it seemed that Toshimi was the happiest member of the Kobayashi household.

Harumi's restlessness was only partly assuaged by her work at the mothers' centers. She played music with the children, and helped distribute packets of powdered milk to the women. (Each child was to receive, as per Allende's directive, $1 / 2$ litre of milk a day.) She even assisted in teaching basic hygiene: how to boil the water in which the dried milk would be mixed. She told me how communal water taps had already been installed in many poblaciones, providing them with a supply of municipal drinking water; how medical care was now available for poor working families at polyclinics throughout the city; how many more children and even adults were attending neighborhood schools and literacy classes. For the poor, these were luxuries almost unheard of before Allende's election, and Harumi was glad to play a part in improving living conditions for so many. 
But this work for Allende's "Revolution" wasn't enough. She wanted to travel abroad, see the world. Her restlessness would have been regarded as typical for North American college students from the middle class. Unlike most North Americans, though, Harumi wanted to look around for another country in which to settle. Even then, less than two years into Allende's six-year term, there were disturbing rumors: Popular Unity supporters knew it would not go well for them if the president were to fall.

Harumi planned to leave Chile in about two years, after she finished at the Art School. "Maybe I'll work on a boat," she said, "sail to San Francisco. Or else New York. I might try to go to Cuba, see what it's really like." She pulled out her quena, played a short melody, put the flute back in her jacket pocket. "Then there's Horacio. I don't know what's going to happen with him."

Horacio was the charango player for Inti-Illimani. It was from him that she was learning charango and quena, but she always mentioned him with a tone of uncertainty. I wondered if the lessons were not in part a pretext to spend time with him.

The group was one of the most dynamic of the New Song movement. All its members were working-class scholarship holders at the State Technical University, beneficiaries of the recent tuition remission policy that enabled poorer students to pursue higher technical training. Their first album listed their courses of study-electrical engineering, mechanical engineering, metallurgy - after their names and the instruments they played. The label under which they had recorded was JJCC ("Jota Jota" for short), the abbreviation for the Juventud Comunista. It was common knowledge that they were all members of the Party.

We were at the entrance to the Peña by now. A young bearded man in a poncho took our money and stamped our hands. We went down the dim hallway, past the galería de artesanía. A few people were looking at the handwoven rugs, ceramics and enamelled copperware produced by artisans from the provinces and poblaciones, who had formed cooperatives to sell their work at the Peña. I also stopped to look, but Harumi wanted to get seats first near the front before the place filled up. We collected one glass of wine each (included in the cover charge), and found a low table beside the stage. Harumi set her glass down and took off her poncho. "I'm going to say hello to Horacio." She moved through the tables to the back of the room. 
I looked around. There were young couples, the men bearded and wearing ponchos, the women in woven Peruvian skirts. At one table in the back, a group of large blond men: tourists or diplomats. On the wall behind the stage were photos of Allende; elsewhere, bright silk-screened posters announcing concerts, theatre productions, rallies. The stage was a low platform with a few stools and microphones, one spotlight trained on it from above. Except for light from a door to the patio, where an outdoor kitchen served hot empanandas whose odor drifted into the room, there was no other illumination.

Harumi returned. "I couldn't talk to him. They're rehearsing in the back." She sat down roughly and took a gulp of her wine. The first group came on stage: Los Curacas, five young men in blue jeans, carrying their instruments. They played a series of spirited dance melodies from the altiplano: plaintive huaynos and wifalitas, trotes and marching-band festival tunes from the Lake Titicaca region, filled with out-of-key cheer and drunken-stagger snare-drum rhythms. The audience was soon clapping along.

I kept looking at the bombo player. He sat in front of me on the lip of the stage, in the half-darkness outside the spotlight, cradling the big drum under one arm, his gaunt profile in deep shadow. There was a strange inertness to his presence, as if his hands, manipulating the drumsticks in the music's precise and powerful rhythms, belonged to someone else. He was Alberto Zapicán-older now, and more severe-looking than in the photo on Violeta's final album, like a character from a story who had stepped out beyond the pages, still keeping to himself the secrets the narrative never revealed.

What happened to the members of Los Curacas after the coup is also unknown to me. Their music, at least that which they played at the Peña every week during those months in the middle of Allende's term, was instrumental and almost entirely traditional. There were no strong vocalists among them, hence very few songs in their repertoire with any lyrics, political or otherwise. It was true that the Andean folk melodies and rhythms they performed were the remnants of Inca and Aymara culture which had survived the Spanish conquest and the collapse of the preColumbian kingdoms; and that the revival of this music took place in the context of Popular Unity ascendancy, as part of a general renaissance of pre-Hispanic, indigenous and folk art forms. But there were no overt polit- 
ical subtexts, no specifically contemporary political references in the music Los Curacas played. However, they recorded for DICAP (Discoteca del Cantar Popular, which issued many of the LP's by Peña musicians), and one photo on the back of their first album is potentially damning.

All five are sitting in a close circle with their instruments, as if in an impromptu jam session, in an old-fashioned study before a carved rolltop desk with glass-doored bookshelves on either side. A Venezuelan cuatro, a small four-stringed guitar, hangs on the wall behind them. Facing out from one of the bookshelves is a paperback volume with a photo silkscreen portrait on its cover: the likeness, even through the glass doors, is unmistakeably Allende's.

That portrait, like Alberto Zapicán's photo on the back of Violeta's album, is meant as a discreet but clear-cut statement. Hardly more than a year from then, in the chaotic and revenge-filled first days after the coup, the Peña de los Parra would be ransacked, the studios of DICAP vandalized and looted for condemning evidence, the master tapes destroyed. The political sympathies implied in that LP cover photo would have been enough to have the members of Los Curacas rounded up and imprisoned.

I do not know if any of their music survives in Chile. My copies of their first two albums are scratched with use by now. I have never found any of their recordings - cassettes made from copies of the original albums smuggled out of Chile after the coup - for sale at Latin American solidarity functions, as I have the Allende-era recordings of Inti-Illimani, Quilapayún, Victor Jara. Sometimes I wonder if my two worn albums are the only ones left, the only evidence of their recordings still in existence.

There were other musicians at the Peña on those nights - Tito Fernández, "el Temucano," from Pablo Neruda's boyhood city in the South, who sang and narrated his long original ballads in campesino dialect: bittersweet stories of friends tipsy on payday, of the impossible love between a fieldworker and his patrón's daughter, of an old village couple with a new house, reliving the early days of their marriage now that their children are grown and gone. There was Osvaldo Rodríguez, singing about his boyhood on the rain-washed hills of the port-city, Valparaíso, confessing his youthful fear of poverty and his hope for peace in Chile's new "time for living" (the title of his first album). He sang of the student movement in Chile, and of the Vietnam War, and of his visit to the memorial gravesite 
of slain Spanish poet Federico García Lorca, "beneath the almond tree."

Osvaldo always drove up from the coast to play at the Peña; his niece was a friend of Harumi's, and introduced us to him once. Another night, when I went to the Peña by myself, he recognized me. As he came over, smiling - "Hola, gringa!" - to give me a kiss on the cheek, the customary greeting of friends in Chile, I was surprised at how small he was: not even my height. He seemed so much larger than life onstage. I was also surprised, and pleased, by his friendliness: not all Peña musicians were so welcoming of visitors from the United States.

Osvaldo, I hear, has lived in Mexico since the coup, recording and touring. I do not know what happened to Tito. About Quilapayún we know: they were fortunate to be on tour in Europe when the coup exploded. Living in Paris since then, they have continued to perform and compose, and their music has had the luxury to be able to grow in new, non-political directions. After September 1988, when dictator Pinochet relaxed his ban on many former dissidents and Allende supporters, Quilapayún returned home for the first time in fifteen years.

The Peña audience clapped loudly for Los Curacas, for Tito and Osvaldo when they finished their sets. But it cheered when Isabel and Angel Parra stepped onto the stage. These two were Violeta's successors, her living legacy-dark-haired, diminutive, their presence taut with a fiery energy that made the air crackle when they played together. Angel scowled with concentration, his hair falling over his eyes as he wrapped himself around his guitar-a picture of turmoil and passion-his voice resonant with anger hardly contained, breaking on laments fierce with contempt for cruelty and hypocrisy.

One day I asked

"Father, where is God?"

My father looked at me hard

And didn't say a word.

My father died in the mineshaft

At the bottom of the fosse,

Color of miner's blood

On the gold ore of the boss. 
If there's one thing on earth

More important than God,

It's that no one should live better

Because others are spitting blood.

“The Little Questions About God" by Atahualpa Yupanqui

Isabel was clear-eyed and calm, playing bombo to Angel's guitar when they performed together, a steady and persistent counterpoint to his turbulence. Alone, she sang her mother's cuecas, lullabies and ballads, accompanying herself on charango or guitar, her voice richly melodic, a much finer singer's instrument than Violeta's. Brother and sister filled the tiny stage with their presence and with Violeta's spirit. So, as with Osvaldo, it was always a shock to realize how small they were: Angel was dark and wiry as a jockey, Isabel petite as the Vietnamese women who visited the Peña once in their brilliant ao dais.

Isabel and Angel were among the lucky ones after the coup. Angel was arrested and held for several days in the National Stadium, but he was later released, and he and Isabel and their families sought asylum in one of the embassies in Santiago accepting political refugees. They made their way to Mexico City, and stayed there, performing and recording. A few years ago, a friend lent me a tape of music Isabel had composed since the coup: songs of exile, the impossibility of returning to a beloved country, the divided road of the Revolution, the deaths of so many compañeros.

The finest and most wrenching of these was "Como una historia," Isabel's lament for the death of Victor Jara. The moment the song began, its subject was apparent in the melancholy quality of the melody, the haunting lullaby-like refrain. I stopped moving about in my small kitchen and bent over the cassette player to listen. Isabel sang with no embellishments, as if refusing to be comforted; she hummed the refrain as if to soothe the sleeper in his unending rest.

They're years past, still with me now, It was in Santiago, and I came to know you.

The eighteenth of September, I think it was so . . . 
Once again it's September, this grief we remember, And early one morning, death was waiting for you. There'll be no consolation for this grief we share, There'll be no forgetting what they did to you.

The music pouring tinnily out of the cheap borrowed cassette deck, hardly able to compete with the noise from my street, was like a story from another age, another world. And Victor himself had entered history, beyond the ongoing stories of the lives of Isabel and the others who had survived.

I heard Victor Jara play only once, early on in my stay in Chile, perhaps at my first visit to the Peña. All I knew of him then was that he was "hot," by Chilean standards, a rising star whose songs had recently attained great popularity. I got the impression that not long ago he had been a regular at the Peña, performing every week; but that this appearance was a surprise, he was now on his way to an international reputation. The audience seemed a bit too awed by his success, as if, in their minds, he was no longer one of them. But he came out on stage in ordinary street clothes and a worn leather jacket, and played his guitar and sang quite straightforwardly. $\mathrm{He}$ had a lot of earthy energy and was clearly having fun on stage, bantering with the audience, some of whom guffawed just a bit too eagerly, as though anxious to show the others that they were in the know with this famous musician. I didn't much care for his voice - too nasal and unresonant, with a sort of whining quality in the middle register that sounded sarcastic. I would come to prefer Angel Parra's vocal chiaroscuro, his complexities of passion and anger.

But Victor's songs were wonderful, especially the ballad "Te recuerdo Amanda" ("I Remember You, Amanda"), about a young woman who runs through the streets of her town to meet her lover at the factory gate, only to find that he has left his job to join the resistance forces in the mountains, never to return alive. There was the taunting, ironic hit, "Ni chicha ni limoná" ("Neither Fish Nor Fowl"), a challenge to political fence-sitters either to join in the struggle for social reform, or to stop complaining about the changes taking place in Chile. The audience clapped and sang along in the choruses of this song, with its humorous slang and topical allusions that made everyone feel part of the vanguard of the politically aware. Victor ended his set with "La plegaria a un labrador" ("Invocation to 
a Worker"), with lyrics based loosely on the Lord's Prayer. It was to become his most famous song in North America.

Stand up and look at the mountain,

From whence come the sun, the wind, the water.

Together we'll go, united in our blood,

Now is the time that has to be tomorrow ...

Yet though it would bring tears to my eyes, especially in later years and in light of what happened, I was always bothered by "La plegaria"'s being addressed to the worker, as the object of - rather than the companion in - a prayer for a better world for all workers.

Perhaps this thought is too reactionary, based on too traditional a world view. It certainly didn't occur to me then, caught up as I was in Victor's stage presence, the loyalty and fervor of the crowd, my own efforts to follow - in those first weeks of my stay - the nuances of the language with its peculiar Chilean accent, terms, allusions, humor. But later, after entering more fully into life there, I wondered if, in the "new tomorrow" prophesied and yearned for in this and other New Songs, should not all people be equal: no worker elevated above others, as part of some new elite? Those who followed Chile's new political "road" wanted, I was sure, to avoid if they could the mistakes and excesses of Soviet-style socialism. Of course it could be argued that the worker in "La plegaria ..." was only an emblem, a representation of a type. Or was he yet another romanticized, neo-Platonic-hence derived from a capitalist - Ideal, in the guise of Socialist Realism?

I don't know. I don't even know if these would have been the right questions to ask. I didn't articulate them for myself then, and I would not have had the nerve to go up to Victor after his set to ask, even if I had formulated my queries in my best Spanish. Who could say if such theoretical ponderings - as he laughed and smoked and greeted friends and fans in the Peña's tiny courtyard - if such ponderings would have had any meaning for him? In any case, I was an outsider, from the very country whose government was regarded (not incorrectly, it turned out) as the greatest enemy and most powerful opponent of Allende's political experiment.

So I had no right to ask. All I know is that I had the uneasy feeling, even then, that Victor's songs might be a bit too programmatic, too deliberately 
fashioned for the current "onda," the wave of the moment upon whose crest he was so triumphantly riding, in defiance of the right-wing forces quietly plotting their seizure of power. "Ponte en la onda, gringa," Harumi and her friends would kid, teaching me the slang: Get with it, ride the wave of what's really going down. Victor's songs - and this was both their great strength and fatal weakness - were composed in and for the immediacy of that tragically short-lived historical moment. In the tension-ridden political climate of those few years, these songs were sublimely unconcerned with prudence, with the survival of their creator.

Perhaps he was just trying to be fashionable, to be hip and internationally relevant, in songs with references to rifles and armed guerrilla resistance, to the struggles elsewhere in Latin America against the daily violence of entrenched feudal privilege and right-wing military dictatorship. Chile's transition to a government dedicated to accelerated economic and sociopolitical reform through socialism had been peaceful: via the ballot box and the Congressional confirmation of Allende's slim majority in the popular vote. This period would come to a bloody end in little more than three years, not quite halfway through the six-year presidential term.

Contrary to wide-spread disinformation campaigns, Popular Unity supporters and old-line Party members were not stockpiling weapons on a large scale in preparation for a leftist coup. They were, in the main, too poor or middle class, too committed to the democratic process - or too disorganized - for such measures. Allende sympathizers lacked the means to obtain weapons that were readily available to the landowners and industrialists of the right wing and its neo-Fascist offshoots such as Patria $y$ Libertad, with their paramilitary training camps, their family connections to the aristocratic and increasingly anti-Allende officer class of their own Armed Forces, and their growing support from the CIA for destabilization. But any mention in Victor's songs of class struggle or of armed popular resistance in other Latin American countries could be taken to imply greater Popular Unity involvement with violence than really existed. Victor's expression of solidarity with liberation movements elsewhere could even have justified, for some, the brutality of Pinochet's forces after the right-wing coup. And after Victor had identified himself so completely with Allende's doomed government, it was as if the direction and momentum of his career were so bound up with it that he could not have survived its destruction. 
The 18th of September to which Isabel Parra's song referred was Chile's Dieciocho, its Independence Day from Spain. But on September 11, 1973, Salvador Allende and his administration fell in Pinochet's seizure of power. Sometime between the 11th and the 18th - that terrorized, battletorn Dieciocho of denunciations and arrests, house-to-house searches, duskto-dawn curfews, and peremptory on-sight shootings - Victor Jara died in the National Stadium, shot by the soldiers who apparently tortured him first for singing to keep up the spirits of his fellow prisoners.

There are differing versions of this story, of its grisly details, by surviving eye-witnesses and those who claim to be eye-witnesses. One version has been published as a poem in an anthology honoring Pablo Neruda, who also died in Santiago during the coup, on September 23rd, of cancer; but not before Pinochet's troops ransacked and vandalized his home, knocking over bookshelves and burning books and manuscripts, as the Nobel Prizewinning poet lay on his death-bed in another room. In this version, Victor Jara is told to stop singing to his cell-mates. When he refuses, he is led out into the stadium's arena, and in front of thousands detained in the stands, his hands are first broken and then cut off by the guards. He stands free for a moment, still singing, holding up the bleeding stumps to the crowd, before he is gunned down.

I have heard people sob aloud when this poem-version was recited before an audience. But I prefer to believe the less sensational version given by Victor's widow, Joan Jara, in her biography and memoir, An Unfinished Song. Her details are gathered from accounts by several of her husband's prison companions in the last days and hours of his life. They are pieced together from brief glimpses of him being moved from one cell to another, overheard in snatches of conversation between other detainees, memorized from Victor's last verbal message for his wife and daughters when he realized that the officer in charge meant to kill him-details these fellow prisoners risked their lives to report to her later. In Joan Jara's account, she is finally contacted by one compañero of Victor's, and brought to the city morgue to identify and claim her husband's body. She finds him there among hundreds of other dead: he is bruised and gaunt, his hands lying at odd angles to his sides as if the wrists had been broken. "It was Victor, my husband, my lover," she says, simply, in the full enormity of her loss. She makes no mention of any further mutilation.

Why should these varying accounts matter to me-who was not an eye- 
witness in any case, who had already departed Chile before the coup, who met Victor Jara only once? He had become, after all, a public figure in his life; and in death, a symbol of the power of the human spirit, as expressed in song, to resist and triumph over the forces of political repression. Whatever his human failings, in death he became a martyr and a hero, the episodes of his life subject to elaboration, distortion, apocryphal variations. The chaos after the coup, in the streets and in the improvised prison of the National Stadium, lent themselves to the proliferation of versions of Victor's suffering and death. But the bare facts, as they are known, are horrific enough without sensationalizing. Nothing will bring the man back to life: let him, therefore, in the accounts we read and thus in our memories, go to his death without exaggeration.

It is Harumi whose fate remains unknown to me. Unlike the poets and artists, the musicians and organizers of the Peña, she was still a student in Allende's time - but not so obscure as to be ignored by the police after the coup. She was too politically active, and her life, at least when I knew her, was too closely bound up with Horacio and Inti-Illimani. Sometimes she would disappear from the Art School for days at a time; later she would tell me that she'd gone with the Inti on some regional tour, to the mining towns and nitrate "offices" up north - Calama, María Elena, Oficina Victoria - or to the bleak, fogbound, dessicated ports out of which the ore was shipped: Iquique, Antofagasta, Tocopilla. When the Inti were in town, though, she never seemed to go to the Peña or other concert venues with them; but separately, with me or some other non-musician friend. And she would always leave with me, too, riding the bus until I got off at my stop and she continued on - to her parents' place, I supposed. Did she and Horacio want to keep their relationship private, some sort of open secret? During performances, she never concealed her absorption in the music, playing her charango along with them.

The Inti were disciplined performers, far more so at that time than Quilapayún, the other up-and-coming five-member conjunto. Both groups had trained and rehearsed with Victor Jara; both would perform his music, as well as traditional folkloric pieces, in the years to follow. They would become his surviving artistic legacy. But Inti-Illimani were more cohesive and versatile: they had formed on their own at the Technical University, and they paid greater attention to performance techniques - clear enuncia- 
tion, precise rhythm and timing, strong ensemble playing and harmonizing. All were good vocalists; and besides their principal instruments (guitar, charango, quena, bombo), all could play any number of othersmarimba, conga drums, maracas - required for their varied repertoire of Andean, Argentine, Mexican, Cuban, West Indian and Spanish music, as well as their own compositions. And, unlike other New Song groups, they all dressed alike onstage, at that time in deep red ponchos with black fringe, over dark trousers.

It was impressive to watch them file slowly, in step, onto the stage under the Peña's single spotlight, chanting a stately festival song - "Negra, samba, coge tu mante, siempre adelante..."- a song urging the native woman to take her shawl and lead the dances with which the Aymara and Quechua people, descending from the mountains and altiplano to the tiny Atacama desert town of La Tirana, brightened their harsh lives. The Tirana festival, held every winter, had by then become a tourist attraction as well, drawing visitors from Santiago, La Paz, even Lima and Mendoza. The Inti were to perform there this year, and Harumi planned to go with them.

I was flattered, of course, to meet Inti-Illimani at the Peña through Harumi, and to have a sort of personal connection with them because of her. They were affable enough, teasing me about being a gringa and no doubt working for "la CIA" (they pronounced it see-ah). I teased them back, saying that of course they were all first on my hit list. They laughed-I don't suppose anyone really believed I was an informer or spy - but Horacio didn't think it was funny. He scowled, and turned away to pack up instruments.

It seemed that he was the group's leader, a little older than the othersin his early thirties - stockily built, with rust-colored hair that curled in ridges, like those Galician Spaniards who could be Irish. He talked fast, hardly moving his lips, in the clipped working-class Santiago accent I found hard to understand. I never did feel at ease with him, and he appeared to endure my presence for Harumi's sake.

For some reason, she took me with her one evening to visit him. We rode one of the barrio alto busses, then walked several blocks down quiet tree-lined streets to a small stucco house in the garden behind a larger Spanish Colonial-style residence. Horacio answered the door. The interior was uncomplicated and tasteful $-\mathrm{a}$ few hand-loomed tapestries in bright primary colors on the walls, covers in similar patterns on the sofa cushions, a 
striped rug from Temuco on the polished wooden floor. Against the wall, on another rug woven in natural dark browns and grays, was a collection of instruments: guitars, bombos, charangos, a xylophone, Pan-pipe zampoñas in graduated sizes. There was a good stereo system with floor speakers; through an open door, a small darkened bedroom, impression of a kitchen beyond it through another door. I sat on the floor near the instruments.

Horacio brought wine in glasses, and sat beside Harumi on the sofa to roll a joint. They picked up two of the charangos from his collection and he began to play a strumming pattern over and over, explaining something about it to her in his clipped accent. I didn't try to follow. Harumi was nodding, smiling, dipping her head so that her black hair swung forward. She played the strumming pattern slowly, then again. Now and then she stopped, shook her head self-consciously, then looked at Horacio, who smiled and muttered something that made her flush. He took her left hand in both of his, and arranged her fingers on the charango's neck, showing her how to fret better. I sipped my wine, studied the instrument collection, and gazed at the tapestries on the walls. Soon they took a break, lit the joint, passed it to me. They poured more wine, and resumed practicing.

After a while, Horacio turned on his small TV: a speech of Allende's was going to be broadcast. Harumi put down her charango and sat on the floor in front of the set, next to Horacio. I stared at the tiny image of the president inside the television screen, but could make no sense of the speech. Allende's arguments seemed to dissolve, then the individual Spanish words ceased to have any meaning. There was a barrier between me and the sound coming from the TV. I felt my identity drain away with the language, and no English came to replace it.

What language was I thinking in then? I looked at Harumi and Horacio, huddled close together and silhouetted in the light from the TV screen, absorbed in the speech, his hand straying over her back now and then. They could have been miles away. What was I doing in this country, with these people, trying to understand their reality? The room seemed to pulsate with hostile energies, or was it merely indifference? I was completely alone here. If I continued thinking like this, I would freak out. I didn't dare let that happen. I had to change the atmosphere, break the downward spiralling of my thoughts.

I started to babble something (in Spanish? English? dimly, with relief, I realized it was Spanish) about how good it was that Allende was uttering 
these truths (what truths? I hadn't understood a word he was saying, but all these speeches said pretty much the same thing, I hoped) about a better life for the people, about a government in which everyone could participate ... (Harumi and Horacio had turned and were staring at me). What Nixon and Kissinger were doing with the trade embargo, and the Vietnam War which of course all people my age in America opposed . . . (I was warming to my subject, beginning to feel better) . . . but it was wonderful the way so many Chileans were working for the Revolution, and . . .

"Gringa," Horacio interrupted me. "You don't know anything about the Revolution."

"What do you mean?" I must have replied, stupidly, inviting his ad hominem re-education lecture.

"You have the same petite bourgeois misconceptions of our president and our politics as all your gringo countrymen. You have no understanding of the dialectical process, and no idea of the struggles that are really taking place in this socio-economic context ..." He went on to tell me what was wrong with my attitude toward Chile, and wrong with my being in his country; furthermore, what was wrong with my country's foreign policy, wrong with gringos in general and me in particular. I don't remember any more of the specifics, only the overall tenor of his invective, the conflation of my and my country's sins. Never-whether as a Fulbright scholar or a mere private citizen - had I so thoroughly and completely represented the United States of America, as I did at that moment, when I stood for all that was evil in it.

The only other thing I remember from that confrontation is Harumi: sitting there in silence, beside Horacio, gazing at me, nodding occasionally at some point of his, making no attempt to defend me. Once, she leaned toward him to make a comment - perhaps to modify something he was saying, because he broke off, asked her a question, nodded at the reply, and resumed his tirade with a little less virulence.

I have no idea what expression was on my face then, though I probably nodded in acknowledgement a few times, whether or not I agreed with Horacio's accusations. (Is this what is meant by Marxist-Leninist self-criticism? I wondered.) I may have asked, as evenly as I could, if-after less than a year in Chile - I could be expected to understand the country as well as someone who had lived there all her life? Or if, at the age of twentytwo, and not yet having voted in any of my country's elections (the 
Twenty-Sixth Amendment to the Constitution, lowering the voting age to eighteen, was ratified on July 1, 1971, the day before my twenty-second birthday), I could be held responsible for the entire United States foreign policy?

Most likely I did not ask these questions. My memory of them is probably wit-of-the-staircase wishful thinking. But although I may not have defended myself, I know that I did not, after all, freak out. Now that I had real antagonism, real alienation to deal with, the herb-induced clouds of anxiety cleared away. I was not going to give them the satisfaction of seeing the gringa fall apart under pressure, ideological or otherwise.

At some point, the re-education session was terminated, the television (by then showing one of the national sit-coms) was turned off, tea was served, and the charango lesson concluded. How the evening ended I'm not certain. Harumi and I may have walked back to the bus stop together, but whether she got on with me or returned to Horacio's for the night, I don't recall. From then on, though, I determined not to call her, not to seek her out. I had had enough of the dialectical process's thesis and antithesis; it didn't seem possible to achieve a synthesis.

A few days later, however, she came up to me at the Art School, cheerful and friendly, asking me if I wanted to go to a "Jota Jota" meeting with her. "So you can get a better idea of, you know, our struggle here." It seemed that the Inti were going to perform at the meeting. "But Horacio's cool," she said. "I talked to him, he doesn't think you're a reactionary."

The meeting was held in the Art School auditorium. Besides Harumi and myself, only about a dozen students attended-all with the straight black hair and mestizo features that marked their proletarian origins. The three speakers, two men and a woman, dressed in blue jeans and denim jackets or ponchos, sat at a table on the stage. Only one of them, a young man with shoulder-length black hair and a black and red woven headband, actually spoke, addressing his small audience in the rapid-fire dialect of the urban poor. I leaned forward to try to follow his words - something about the new means of production, the solidarity of the workers. But I was interested less in his message than in another young man, a stocky mestizo in denim, who stood to one side of the stage, taking pictures of the audience with an SLR camera. He moved across the stage, behind the speakers' table, to get shots from the opposite angle; then into the aisles for a few more photos, before he sat down by himself in the front row. 
Who are those pictures intended for? I wondered. What file will they go into? Who will see them, and what will they do with the information? Along with the photos, I could imagine a list of names of those attending this meeting, their addresses, names and ages of their family members. Perhaps I was merely paranoid-more under the influence of Horacio and his sort than I realized - but I felt an odd premonitory chill. These people were employing the same sorts of information-gathering tactics they accused their supposed ideological foes of using, only these Communist Youth were far more crude and obvious about it. Whatever "Jota Jota's" purpose for these photos, whatever desk drawer of some office of the Partido they would be stored in, they may have, after the coup, fulfilled all too well their informational function. If they fell into the hands of the military police, how many of these young working-class art students-Harumi among them - might have been arrested, imprisoned, made to disappear? I, too, was in those pictures, but I would be back in the United States by the time of the coup.

The Juventud Comunista meeting was, ultimately, boring, as were all such meetings and educational cell groups I attended there. Nothing could make a lecture-discussion of Das Kapital, even in Spanish translation, any less dry and devoid of human spirit, human warmth. Human beings could never be, for me, members of a species motivated solely by economic drives. What intrigued me about the so-called Chilean road to socialism was not its ideational dimension, but the idealism that fired the imaginations of so many people I knew there, even the proto-ideologues of the "Jota Jota." And what mattered to me at this meeting was that afterwards, in the confusion of greetings and plans for weekend volunteer work in the poblaciones, Harumi began to introduce me to the others as her compañera, her hermana: her comrade and sister. I was honored-and embarrassed - to be included like this, but at that moment, in company with Harumi, I almost felt I belonged.

There would be little time left, though, for me to involve myself in the revolutionary process: my time in Chile was drawing to a close. A few days before my departure, I gave a farewell party. There wasn't enough space in the house where I had been staying, so it was held in the family room of the house of another Art School friend, Pato Téllez. Pato belonged more or less to the same social set as Rogerio, though they were not really friends. 
Pato's father managed a branch of the Banco Central de Chile; his older brother had some sort of import-export business, and made frequent trips to Miami. Pato himself had spent a few school holidays there with his brother and sister-in-law, on the beach. But unlike Rogerio and his crowd, Pato was interested in theatre, dance, and music. On weekends, if he wasn't out with his girlfriend - a demanding, tennis-and hunt-club, Providencia Avenue type he sometimes complained about to me during the printmaking workshop - he would drive us to the Peña in his Austin Mini. In fact, he met Harumi and her friends, he said, through me, even though they had all been at the Art School for a couple of years before I arrived.

One of the times he drove me home from the Peña and we sat outside in his car, talking, he told me that I had accomplished a minor miracle among the different social circles in the little world of the Art School. "You've gotten us all to start talking to each other," he said. "We might have graduated without ever speaking. You've got a real talent for getting people together, gringa." It was one of the most gratifying compliments paid to me by anyone in Chile.

I enjoyed watching him dance a few times at my party with Harumi, when she wasn't ladling out sangria or supervising Vicente and his companera Claudia in bringing trays of hot empanadas from the kitchen. Another friend, Esteban, had brought his guitar, and with Vicente on flute and Harumi on charango, we sang a few of the Peña's most popular numbers: "Vamos subiendo la cresta, vamos llegando al final ..." ("Let's climb to the top, let's reach our goal"); some of Violeta Parra's cuecas; and, of course, "Venceremos." The Inti had all been invited, and toward the end of the evening, Horacio showed up alone, and hovered outside on the patio, talking to Harumi. I brought him a glass of sangria and some empanadas on a paper plate, and invited him to join us inside.

After a few minutes, Harumi came in by herself, looking troubled. "I have to go now," she said, and embraced me, her hermana, several times. She and Pato would meet me at the Braniff office, though, on Thursday, and see me off at the airport.

"Take care," I told her. "I hope everything's all right." She shook her head - no or yes, I couldn't tell which-and disappeared out the door. I never saw her again.

Neither she nor Pato showed up at the Braniff office. I spent all that morning calling taxi companies, trying to persuade them to send a cab for 
me. Every dispatcher refused, saying "Too dangerous, señorita, too much trouble downtown"; or "No taxis running, no spare parts, we can't repair them." Pato would have given me a ride, but his car had also been having engine trouble. When I finally succeeded in getting a taxi, the driver could take me only to the edge of the downtown area. One of the by then daily demonstrations (one day for, the next day against Allende) was underway, and the entire district was barricaded off. I had to entrust all my luggage to the taxi while I dashed several blocks, handkerchief over my nose against tear gas fumes, to the Braniff office. It was closed, metal grate reja lowered. From inside the darkened glass doors, the security guard handed me my passport, with its 24-hour salvoconducto pass which permitted me to leave the country that day. I made it to Pudahuel just in time for my flight.

A few weeks later, I received a cheerful, chatty letter from Pato, lamenting the comedy of errors by which he and Harumi had missed each other at their pre-arranged meeting point. It had turned out to be smack in the middle of the demonstration route, and each of them lost so much time waiting for the other that they reached Braniff too late. Pato even drew a humorous little diagram of their respective positions on opposite corners, as they looked for and failed to find each other.

A letter from Harumi arrived several days after that. She was sorry she had missed me, sorry she hadn't written sooner, but she and Horacio had been breaking up. It was a time of struggle for her, she said, but part of the process even if she was impatient with it, even if she wanted to get on to more important political issues. I wrote back right away, and her response was more cheerful. She had met a Cuban, who was working as a book designer for one of the pro-Allende publishing houses. He'd invited her to visit his country with him after she finished at the Art School.

Her last letter was dated June 21, 1973, just before the tancazo, the aborted coup attempt that set the entire country on edge. She was living with her Cuban by then; they were planning to visit Cuba as soon as he could get leave from his job. In fact, they were thinking they might "join two roads together" - as Harumi put it - a fact which infuriated her parents, because her friend, like many Cubans, was of mixed African and Hispanic descent. She joked about her old dream of working on a boat, and said she might still end up in San Francisco one of these days. "Who knows what could happen?" she wrote. I wrote back to say that she should call me collect from the Haight-Ashbury when she arrived - I was only half 
kidding - and I would drive down to meet her and show her around.

I don't know if she ever received that letter. A week or so after I sent it, I was involved in a bicycle accident which sent me to the hospital for stitches and emergency dental work. The next evening, my housemates woke me from a convalescent stupor to say "Come look at the news." There had been a coup in Chile, Allende had been killed, and hundreds of his supporters arrested and shot. Through a haze of painkillers, I watched some of the satellite footage: the skirmishes in the streets, the arrests, the jets flying overhead in the aerial bombardment of the Moneda palace, where Allende had been gunned down in his office. I could barely stand, I had to return to my bed and lie there in a daze edged with unreality and the sorrow of what I had just witnessed on the television. I thought of my last sight of Harumi, walking away from Pato's house with Horacio, head down, carrying her charango, her shadow under the street lamp belonging to no one.

I never heard from Harumi again, nor from any of the other friendsAllende supporters and opponents - with whom I had been corresponding. I have no idea where they are, or which ones among them are still living, which ones dead. But I do know about the members of Inti-Illimani. They were on tour in Europe on September 11, 1973; and simply remained there, not to return to Chile for fifteen years. Then, just before the National Plebiscite which would give a negative vote to his regime, Pinochet lifted his ban on exiled Popular Unity supporters, and allowed many-Allende's widow, Hortensia Bussi, daughter Isabel, dissident intellectuals such as Ariel Dorfman, and former musicians of the Peña de los Parra - to visit their native land openly for the first time since the coup.

In those fifteen years, the Inti stayed together: all settling in Italy, losing and gaining (as far as I can discern from the group photos on album covers) only one member, performing throughout the world and making a dozen or more recordings - reissues of their old DICAP LP's, live concert tapes of New Song material, and many new and innovative compositions of their own. Friends of mine bought cassettes of their music in a shop in the Frankfurt airport, others heard them play in Amsterdam or Barcelona. Since the mid-1970s, I myself have missed, by only a day or two, concert appearances of theirs in Boston, San Francisco, and Seattle; and I have read the reviews later, clipped from the newspapers. I have studied the press-kit photos, and observed the lines deepening in their faces, the scattering of 
gray in Horacio Durán's red hair: signs of the passing of time for those lucky-or shrewd-enough to have been elsewhere at the right time, to have survived. Someday I will attend a performance of theirs, and I will wheedle or bribe my way backstage, to tell them, in Spanish that is still Chilean-accented, that I knew them in Santiago, at the Peña, durante Allende. I will introduce myself to Horacio: "Do you remember the gringa, Harumi Kobayashi's friend, the one whose political views you corrected?" Then, even if he doesn't remember, I will ask him the one question I've really come for: What happened to Harumi? If he can tell me, I will be able to finish this story.

Note: Excerpts from songs cited here are in my translation. 